DOI: https://doi.org/10.32839/2304-5809/2021-8-96-3

УДК 347.948

Собакарь Є.М., Шитова Л.В.

Харківський науково-дослідний експертно-криміналістичний центр

Міністерства внутрішніх справ України

\title{
ОЦІНКА ЯКОСТІ КАВИ
}

Анотація. Статтю присвячено вивченню теоретико-методологічних основ оцінки якості кави: натуральної обсмаженої в зернах та меленої, натуральної розчинної кави. Визначено основні нормативні акти для оцінки якості кави. Розглянуто органолептичні показники якості кави обсмаженої в зернах, зокрема, аромат, колір і форма, вигляд на розріз, вміст вологи, неякісних зерен, органічних і мінеральних домішок. Дано загальну характеристику показників для оцінки кави натуральної розчинної (за типами: порошкоподібна, гранульована, сублімована. Встановлено, що наявні нормативні документи свідчать про сформовану основу технічного регулювання управління якістю кави в Україні. Виявлено, що аспект органолептичних досліджень якості кави, які безпосередньо пов'язують сортність та вартість кави не має належного нормативного регламентування.

Ключові слова: оцінка якості кави, управління якістю кави, товарознавча експертиза, дослідження кави натуральної в зернах, дослідження кави натуральної розчинної.

Sobakar Yevhen, Shytova Liliia Kharkiv Scientific Research Forensic Center of the Ministry of Internal Affairs of Ukraine

\section{COFFEE QUALITY ASSESSMENT}

Summary. The article is devoted to the study of theoretical and methodological bases of coffee quality assessment of evaluation of natural coffee roasted beans and ground coffee, natural instant coffee. One of the main tasks of coffee quality assessment is to determine compliance with the norms of organoleptic parameters of the studied samples. The color, taste, appearance of coffee not only indicate the presence or absence of impurities (counterfeit), and also characterize the origin and quality of the grains themselves, compliance with the technology of collection, cleaning, frying, packaging. The objectives of the article are to summarize the criteria and indicators for assessing the quality of natural roasted coffee (ground beans) and instant coffee. Were identified the main regulations for assessing the quality of coffee. Also were considered organoleptic indicators of quality of coffee roasted in beans, in particular, flavor, color, shape, cut to shape, moisture content, low quality beans, organic and mineral impurities. Also were described general indicators for the evaluation of natural instant coffee by types: powder, granular, sublimated. It is concluded that the available regulations indicate the basis of technical regulation of coffee quality management in Ukraine. These documents set out the criteria for the composition of products, acceptable levels of impurities, identify and describe the main methods of safety control of coffee, also set out requirements for labeling and packaging of coffee. At the same time, the organoleptic characteristics of coffee by varieties remain insufficiently covered. Their thorough study involves recourse to scientific sources and recommendations of international organizations of coffee producers and importers. Aspects of organoleptic studies of coffee quality that directly link the quality and cost of coffee, does not have proper regulations. The theoretical principles of coffee quality assessment considered in the article are based on: a) research methodologies according to the relevant national standard; b) scoring methodology, which provides a comparative assessment of consumer qualities of coffee in accordance with its varietal characteristics. We see prospects for further research in the development of theoretical and methodological foundations for assessing the quality of varietal coffee based on international coffee quality management standards.

Keywords: coffee quality assessment, coffee quality management, commodity expertise, research of natural coffee beans, research of instant coffee.

Постановка проблеми. Специфріка кави як об'єкта товарознавчої експертизи зумовлена тим, що цей продукт належить до смакових товарів. Одне із основних завдань оцінки якості кави полягає у визначені відповідності нормам органолептичних показників досліджуваних зразків. Колір, смак, зовнішній вигляд кави не лише свідчать про наявність або відсутність домішок (фальсифікату), але й характеризують походження та якість самих зерен, дотримання технології збору, очищення, обсмаження, фрасування та інших технологічних процесів.

Попри наявність значної кількості нормативних документів про якість кави, присвячених різним аспектам оцінки якості кави (зеленої, обсмаженої в зернах, меленої, розчинної), нинішній стан розвитку нормативної методології оцінки якості кави - як продукту готового до споживання - зали- шається незадовільним. Тому ощінка якості кави як об'єкта експертної товарознавчої експертизи досі залишаеться дискусійним питанням.

Огляд останніх досліджень і публікацій. Методологічні аспекти проведення товарознавчих досліджень смакових товарів викладено у працях таких дослідників як I. Сирохман, Т. Раситюк, В. Шкарупа та ін. Питання якості кави за органолептичними показниками розглядали такі науковці як Г. Міневич, Л. Баля, Т. Кунділовська та ін. Проблематика управління якістю кави - 3 точки зору виконання вимог вітчизняних та міжнародних стандартів на різних етапах виробництва кави вивчали О. Зибарева, Т. Воронюк, О. Лучик та ін.

Виділення невирішених раніше частин загальної проблеми. Віддаючи належне внеску попередників, відзначимо, що попри наяв- 
ність фрахових товарознавчих досліджень якості кави, все ж невирішеним залишається питання стандартизації критеріїв та показників якості різних видів кави: зеленої, обсмаженої в зернах, меленої, розчинної.

Цілі статті полягають в узагальненні критеріїв та показників для оцінки якості натуральної обсмаженої кави (в зернах те меленої) та розчинної кави.

Виклад основного матеріалу дослідження. Кава як продукт кінцевого споживання проходить ряд технологічних процесів від збору до фрасування готового продукту для продажу споживачам. На кожному із цих етапів висуваються певні профресійні та нормативні вимоги. У нормативному полі країн-виробників та країн-імпортерів кави діють не лише державні або міжнародні стандарти (ISO), але й стандарти неурядових організацій та асоціацій кави, котрі утворюють основу процесу управління якістю кави. Виробництво кави охоплює такі технологічні етапи:

- якість вирощування;

- якість первинної обробки;

- якість зеленого зерна;

- якість обсмаженого зерна та якість перероблення кави на розчинну каву та/або на розчинну каву;

- якість фрасування та пакування кави.

На кожному з щих етапів $є$ імовірним порушення технології виробництва, змішування кави з сторонніми речовинами чи змішування з сировиною нижчого сорту; кожен із цих чинників негативно впливає на споживчі якості кінцевого продукту.

Нормативне регулювання якості кави на різних технологічних етапах проведено у загальних стандартах (наприклад, ISO 22000:2018 «Система управління безпечністю харчових продуктів» та ряді спеціальних стандартів. Для зеленої та сирої кави цими стандартами є:

- ДСТУ ISO 4149:2016 «Кава зелена сира. Методи візуального дослідження і визначання запаху, вмісту сторонніх домішок і дефектів»;

- ДСТУ ISO 4150:2018 «Кава зелена або сира. Визначення розмірів ручним та машинним просіюванням»;

- ДСТУ ISO 6667:2005 «Кава зелена. Визначення кількісного співвідношення зерен, пошкоджених комахами»;

- ДСТУ ISO 6668:2018 «Кава зелена. Підготування зразків для органолептичного аналізування»;

- ДСТУ ISO 6669:2004 «Кава зелена і смажена. Загальний метод визначення об'ємної щільності вільно насипаних цілих зерен» [2, с. 5-6], та ін.

Для кави натуральної смаженої в зернах - ДСТУ 6805-97 «Кава натуральна смажена в зернах» та ДСТУ ISO 10095:2005 «Кава. Метод визначення вмісту кофеїну з використанням високоефективної рідинної хроматографії» та ін.

Для кави меленої та розчинної:

- ДСТУ ISO 11817:2016 «Кава мелена смажена. Визначення масової частки вологи. Метод Карла Фішера (контрольний метод)»;

- ДСТУ 4394:2019 «Кава натуральна розчинна. Загальні технічні умови»;

- ДСТУ ISO 11292:2007 «Кава розчинна. Визначення вмісту вільних і загальних вуглеводів методом високоедективної аніоннообмінної хроматографії» та ін.
Наявні нормативні документи свідчать про сорормовану основу технічного регулювання управління якістю кави в Україні: висунуто критерії до складу продукції, допустимих рівнів домішок, визначено та описано основні методи контролю безпечності кави, висунуто вимоги до маркування і пакування. Разом із тим, недостатньо висвітленими залишаються органолептичні показники кави, грунтовне дослідження яких передбачає звернення до наукових джерел, оскільки запропоновані у нормативних документах методи ощінки (наприклад, у ДСТУ 4394) не дають змогу об’єктивно дослідити продукт [4, с. 454; 5, с. 127].

У цьому зв'язку, для формування системи оціночних органолептичних показників доцільним є звернення до рекомендацій міжнародних спеціалізованих стандартів (наприклад, Speciality Coffee Organisation, Cup of Excellence Standarts та ін.).

Також слід додати, що за основу методології оцінки органолептичних показників усіх видів кави доцільно використовувати відповідну розробку Т. Кунділовської. «При використанні такої шкали для кожного продукту виділяеться певна кількість важливих саме для нього органолептичних показників: смак, запах, зовнішній вигляд, консистенція. Для цих показників визначаються коефіцієнти вагомості, що вказують на важливість показника при фрормуванні споживчої цінності продукції» [4, с. 454].

Таким чином, теоретико-методологічною основою оцінки якості кави з метою виявлення їі фрактичної споживчої цінності є: а) методологія дослідження, описана у відповідному "кавовому» стандарті; б) методологія бальної оцінки, яка передбачає розширену оцінку споживчих якостей кави.

Органолептичні показники кави обсмаженої в зернах доцільно згрупувати за такими критеріями оцінки:

- аромат, колір, форма, вигляд у розріз;

- маса та кількість зерен у 1 дм куб.;

- вміст вологи, неякісних зерен, органічних і мінеральних домішок.

Оцінка показників першої групи критеріїв ощінки має на меті підтвердження відповідності заявленої у специфікації договору (на упаковці) сортової, сортної та видової належності кави.

Сортову належність кави досліджують на основі типових характеристик основних сортів кави за походженнял: наприклад, Плантейшн А (Індія), Чері (Індія), Йоргачіфр (Ефріопія), Джимма (Ефіопія), Санто (Бразилія), Меделін (Колумбія) та ін; за типол сорту: звичайний або пібері; за видол кави: арабіка або робуста та ін.

Вивчення сортної належності полягає у виявленні дефектних зерен та оцінці їх кількості у загальній масі, а також у вивченні якості обсмаження зерна. (за кольором кавових зерен). Якість обсмаження можливо оцінювати за загальними критеріями: світле, середне, темне), або за специфікою сорту кави: якісна підготовка кави кожного сорту передбачає створення спеціальних умов для обжарювання зерен (температура та тривалість обсмаження), які найкраще розкривають аромат того чи іншого сорту.

Ключова ознака сортності кави в зернах за обсмаженням - рівномірність обсмаження. Зерна вищого сорту мають бути рівномірно обсмаженими до коричневого кольору з матовою або блис- 
кучою поверхнею; зерна кави 1 сорту - можуть містити зерна темнішого або світлішого відтінку відносно основного кольору.

Маса та кількість зерен у 1 дм куб. оцінюються відповідно до встановлених нормативів. Наприклад, для Плантейшн А (Індія) нормативним є 4350 зерен у 1 дм куб., для Чері (Індія) - 4300, Сантос (Бразилія) - 5000 та ін.

Методологія дослідження та допустимі норми вмісту вологи, органічних і мінеральних домішок визначено нормативними документами. Граничні показники становлять: вмісту вологи 4-7\% (для натуральної обсмаженої кави), масової частки золи - не більше 5\%; масова частка металічних домішок - не більше 5 мг на 1 кг кави; масова частка екстрактивних речовин - від $20 \%$.

Відповідно до вимог ДСТУ, зовнішній вигляд i колір кави натуральної обсмаженої меленої та кави розчинної визначають візуально при визначають візуально при денному світлі або люмінесцентному освітленні в частині об’єднаної проби продукту, яку поміщають на лист білого паперу рівним шаром. Кава мелена вищого і 1-го сорту є порошок коричневого кольору 3 включенням оболонок кавових зерен, у 2-го сорту - порошок темно-коричневого кольору. Аромат визначають у сухому продукті і приготовленому напої. Смак визначають тільки в приготованому напої [1].

Методологію порівняльного органолептичного дослідження кави розчинної (порошкоподібної, гранульованої, сублімованої) детально описано Т. Кунділовською. Вона передбачає оцінювання розчинної кави за 5-тибальною шкалою: смаку, аромату, кольору, зовнішнього вигляду [4, с. 456].

Смак кави розчинної відповідає смаку кави натуральної, 3 якої вона отримана. Смак натуральної кави формується під час її обсмаження і залежить від дубильних речовин, кислот, продуктів карамелізації, що утворюються під дією високих температур. Щоб задовольнити потреби споживача, смак кави має бути гармонійним і типовим для кави. Для цього він повинен бути гірким і кислим, після ковтання повинен залишатися в'яжучий присмак. Можна встановити наступні вимоги до аромату кави натуральної розчинної - його гармонійність, типовість для кави, наявність аромату смаженої кави. Тож, хоча аромат розчинної кави значно бідніший за аромат кави натуральної, він повинен бути при- ємним споживачеві. Для встановлення типовості та «кавовості» смаку та аромату каву розчинну необхідно порівнювати 3 кавою натуральною. Зовнішній вигляд та колір кави розчинної залежать від способу її отримання. Так, кава порошкоподібна представляе собою дрібний порошок коричневого кольору, кава агломерована - крихкі гранули неправильної фрорми, пористі, більш темного кольору. Кава сублімована світліша, має вигляд багатогранних кристалів, приблизно однакових за розміром, проте різноманітних за формою [3, с. 254-255].

Дослідження маркування та упаковки кави має на меті оцінку дотримання виробником вимог законодавства. Зокрема, щодо: наявності етикетки державною мовою, яка містить інфрормацію у доступній для споживача формі; відомостей про безпечне використання продукту (склад, походження, умови та термін зберігання, інформація про дотримання ДСТУ, TУ, ISO під час виробництва та фрасування продукту та ін.). Крім того, етикетка може містити рекомендації чи вказівки про спосіб приготування напою.

Висновки 3 даного дослідження та перспективи. Узагальнення всього вищенаведеного дозволяе констатувати наступне. Наявні нормативні документи свідчать про сформовану основу технічного регулювання управління якістю кави в Україні: висунуто критерії до складу продукції, допустимих рівнів домішок, визначено та описано основні методи контролю безпечності кави, висунуто вимоги до маркування і пакування. Разом із тим, недостатньо висвітленими залишаються органолептичні показники кави, грунтовне дослідження яких передбачає звернення до наукових джерел та рекомендацій міжнародних організацій виробників та імпортерів кави. Аспект органолептичних досліджень якості кави, які безпосередньо пов'язують сортність та вартість кави не має належного нормативного регламентування. Розглянуті у статті теоретичні засади оцінки якості кави побудовано на основі: а) методології дослідженні за відповідним національним стандартом; б) методології бальної оцінки, яка передбачає порівняльну оцінку споживчих якостей кави відповідно до її сортних характеристик.

Перспективи подальших досліджень вбачаємо у розвитку теоретико-методологічних основ оцінки якості сортної кави на основі міжнародних стандартів управління якістю кави.

\section{Список літератури:}

1. ДСТУ 4394:2019 «Кава натуральна розчинна. Загальні технічні умови»: видання офріційне. Київ : ДП УкрНДНЦ, 2019. 26 с.

2. Зибарева О.В., Воронюк Т.А., Лучик О.І. Особливості керування якістю продукщії кав'ярень у контексті підвищення їх конкурентоспроможності. Ефбективна еконоліка. 2019. №10. URL: https://www.economy.nayka.com.ua/ ?op=1\&z=7304 (дата звернення: 01.08.2021).

3. Кунділовська Т.А. Інноваційні підходи до оцінювання кави натуральної розчинної. Товарознавство та інновації. 2011. № 3. С. 249-260.

4. Кунділовська Т.А. Розробка ефективної методики сенсорної оцінки кави натуральної розчинної. Наукові пращі Одеської національної акаделії харчових технологій. 2010. № 38(2). С. 453-458.

5. Міневич Г.Я. Органолептичні дослідження якості кави різних товаровиробників. Вісник ЛТЕУ. Технічні науки. 2016. № 16. С. 127-130.

\section{References:}

1. DSTU 4394:2019 (2019) Kava naturalna rozchynna. Zahalni tekhnichni umovy [Natural instant coffee. General specifications]. Kyiv: DP UkrNDNTs. (in Ukrainian)

2. Zybareva O., Voroniuk T. and Luchyk O. (2019) Osoblyvosti keruvannia yakistiu produktsii kaviaren u konteksti pidvyshchennia yikh konkurentospromozhnosti [Peculiarities of coffee-shops product quality management in 
the context of improving their competitiveness]. Efektyvna ekonomika (electronic journal), vol. 10. Available at: http://www.economy.nayka.com.ua/?op=1\&z=7304 (accessed 01 August 2021).

3. Kundilovska T.A. (2011) Innovatsiini pidkhody do otsiniuvannia kavy naturalnoi rozchynnoi [Innovative approaches to the evaluation of natural instant coffee]. Tovaroznavstvo ta innovatsii, vol. 3, pp. 249-260.

4. Kundilovska T.A. (2010) Rozrobka efektyvnoi metodyky sensornoi otsinky kavy naturalnoi rozchynnoi [Development of an effective method of sensory evaluation of natural instant coffee]. Naukovi pratsi Odeskoi natsionalnoi akademii kharchovykh tekhnolohii, vol. 38, no. 2, pp. 453-458.

5. Minevych H.Ya. (2016) Orhanoleptychni doslidzhennia yakosti kavy riznykh tovarovyrobnykiv [Organoleptic researches of coffee quality of different producers]. Visnyk LTEU. Tekhnichni nauky, vol. 16, pp. 127-130. 